Williamson, G. M. \& White F. (1956). J. gen. Microbiol. 14, 637-642

\title{
Dihydrostreptomycin and Anaerobiosis-Comparison with Other Antibiotics and its Selectivity with regard to Obligate Anaerobes
}

\author{
By G. M. WILLIAMSON AND F. WHITE* \\ Department of Bacteriology, The School of Medicine, Leeds
}

\begin{abstract}
SUMMARY : The sensitivity to various antibiotics of certain facultatively anaerobic bacteria when growing under aerobic or anaerobic conditions was compared. The antibiotics tested were: dihydrostreptomycin, penicillin, chloramphenicol, erythromycin, carbomycin, chlortetracycline, oxytetracycline, tetracycline. Dihydrostreptomycin was unique amongst the antibiotics tested in being less active against facultative anaerobes when they were growing anaerobically than when growing aerobically. Dihydrostreptomycin was relatively inactive against Clostridium relchii and C.novyi, and its action was governed by the inoculum size. Dihydrostreptomycin is not a useful selective agent for the isolation of $C$. welchii.
\end{abstract}

It was observed during routine sensitivity examinations by the ditch-plate technique that streptomycin appeared to have less effect on certain sensitive facultative anaerobes when they were growing anaerobically than upon the same organisms when growing aerobically. There have been several similar observations (Bondi, Dietz \& Spaulding, 1946; Geiger, Green \& Waksman, 1946; May, Voureka \& Fleming, 1947; Grumbach, 1950; Lightbown, 1954). These observations have led to the assumption that streptomycin or dihydrostreptomycin interfere with the oxidative mechanisms of bacterial metabolism. As far as is known, penicillin does not possess this property, but there is little information about other antibiotics (Stokes, 1955). We thought it of interest to compare the effect of penicillin and other antibiotics on facultative anaerobes when growing aerobically or anaerobically.

\section{METHODS}

Organisms. With the exception of Friedländer's bacillus (Klebsiella pneumoniae strain 41; May et al. 1947) and Staphylococcus aureus Oxford strain, the organisms used (Neisseria meningitidis, Haemophilus influenzae type b, Escherichia coli, Aerobacter aerogenes, Streptococcus pyogenes, Diplococcus pneumoniae, Clostridium welchii and C. novyi) were all stock laboratory strains; all were typical by routine laboratory tests. In experiments to test the efficiency of dihydrostreptomycin as a selective agent for the isolation of obligate anaerobes, in particular $C$. welchii, samples of faeces sent to the laboratory for routine examination were used.

Media. Heated blood $(10 \%, \mathrm{v} / \mathrm{v})$ agar $(\mathrm{pH} 7 \cdot 8$; chocolate agar) was used as it satisfied the needs of the most fastidious members of the collection. When dihydrostreptomycin was tested as a selective agent for obligate anaerobes,

* Present address: The Rowett Research Institute, Bucksburn, Aberdeenshire. 
the medium was Robertson's cooked meat medium, either alone or in conjunction with fresh blood $(10 \%, \mathrm{v} / \mathrm{v})$ agar and sterilized milk.

Antibiotics. Dihydrostreptomycin, penicillin, chloramphenicol, erythromycin, carbomycin, chlortetracycline, oxytetracycline and tetracycline were examined. The dihydrostreptornycin sulphate (Glaxo) was dispensed in sterile distilled water in amounts necessary to give the required concentration when $1.0 \mathrm{ml}$. of the antibiotic solution was added to the suspending medium. The other antibiotics were made up in sterile distilled water to give penicillin $100 \mathrm{i} . \mathrm{u} . / \mathrm{ml}$., and the remainder $100 \mu \mathrm{g} . / \mathrm{ml}$; these solutions were further diluted with nutrient agar, when required, to give a final concentration of 20 i.u. $/ \mathrm{ml}$., and $20 \mu \mathrm{g} . / \mathrm{ml}$. respectively.

\section{Comparison of the activity of dihydrostreptomycin with other antibiotics}

Heated blood agar $(25 \mathrm{ml}$.) was poured into Petri dishes of $9 \mathrm{~cm}$. diameter, cooled and dried; a ditch was then cut on one side. Eight groups of six ditch plates were used and the ditches in each group filled with nutrient agar, at $45^{\circ}$, containing either penicillin 20 i.u. $/ \mathrm{ml}$. or $20 \mu \mathrm{g}$. $/ \mathrm{ml}$. of one of the other antibiotics under examination. One standard loopful of an $18 \mathrm{hr}$. culture of the organism under test grown in suitable fluid medium (diluted $1 / 10^{4}$ in nutrient broth in the case of the more vigorously growing organisms, e.g. Escherichia coli and $1 / 10^{2}$ in the case of the less vigorous, e.g. Streptococcus pyogenes) was streaked across the dry surface of the plate, beginning from the edge of the ditch. This procedure ensured that the heaviest inoculum was the first to be exposed to the diffusing antibiotic. Each group of six plates was divided into two sets of three. One set was incubated aerobically and the other anaerobically in a McIntosh and Fildes anaerobic jar for $48 \mathrm{hr}$.

\section{Examination of the action of dihydrostreptomycin on Clostridium welchii}

As previously, triplicate heated blood agar ditch plates were prepared containing $1000,500,200,100$ or $50 \mu \mathrm{g}$. dihydrostreptomycin $/ \mathrm{ml}$. nutrient agar in the ditch. $1 / 10^{1}$ to $1 / 10^{8}$ dilutions of an $18 \mathrm{hr}$. broth culture of Clostridium welchii were prepared and one standard loopful of the undiluted culture and of each dilution streaked across the plate. Parallel experiments were carried out in Robertson's cooked meat medium. Series of tubes containing 1000, 500, 100,50 and $25 \mu \mathrm{g}$. dihydrostreptomycin $/ \mathrm{ml}$. medium were inoculated with $0.034 \mathrm{ml}$. of parent culture and of the $1 / 10^{2}, 1 / 10^{4}, 1 / 10^{6}$ and $1 / 10^{8}$ dilutions used in the experiments on solid media. The plates were examined after $48 \mathrm{hr}$. of anaerobic incubation and cultures in fluid media after $24 \mathrm{hr}$. and 5 days of incubation.

\section{A possible selective medium containing dihydrostreptomycin for the isolation of Clostridium welchii}

Since obligate anaerobes are not inhibited by dihydrostreptomycin, its use as a selective agent for the isolation of Clostridium welchii was investigated. Tubes of cooked meat medium containing decreasing concentrations of dihydrostreptomycin were inoculated with a sample of faeces. A conventional 
test for the isolation of anaerobes was set up in parallel: a tube of cooked meat medium was inoculated and then heated at $65^{\circ}$ for 30 min. (Mackie \& McCartney, 1953). After overnight incubation in air each cooked meat broth culture was subcultured to a fresh-blood agar plate. After further anaerobic incubation for 18-24 hr. these plates were examined for the presence of C. welchii. Typical colonies were examined microscopically and for 'stormy clot' fermentation in sterilized milk.

\section{RESULTS}

\section{Comparison of the activity of dihydrostreptomycin with other antibiotics}

The activity of the antibiotic under investigation toward a number of representative facultative anaerobes growing under aerobic and anaerobic conditions is recorded in Table 1. As controls, a strict aerobe (Neisseria meningitidis) and two obligate anaerobes (Clostridium welchii and $C$. novyi) were included. From this survey it is seen that dihydrostreptomycin was unique among the antibiotics tested in being more effective against facultative anaerobes when

Table 1. Inhibition of growth of a number of anaerobes (facultative and obligate) separately exposed to eight different antibiotics, under aerobic or anaerobic conditions

\begin{tabular}{|c|c|c|c|c|c|c|c|c|c|}
\hline \multirow[b]{2}{*}{ Organism } & & \multicolumn{8}{|c|}{$\begin{array}{l}\text { Linear extent (mm.) of complete inhibition of growth } \\
\text { measured from ditch containing antibiotic }\end{array}$} \\
\hline & $\begin{array}{l}\text { Conditions } \\
\text { of growth }\end{array}$ & 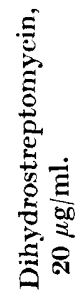 & 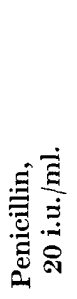 & 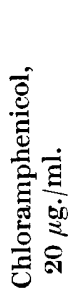 & 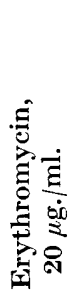 & 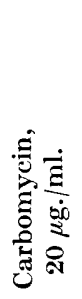 & 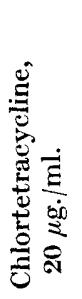 & 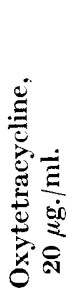 & 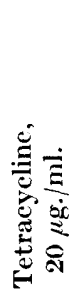 \\
\hline Neisseria meningitidis & Aerobic & $8 \cdot 0$ & $26 \cdot 0$ & $15 \cdot 0$ & $16 \cdot 0$ & $5 \cdot 0$ & $10 \cdot 0$ & $15 \cdot 5$ & $5 \cdot 0$ \\
\hline $\begin{array}{l}\text { Haemophilus influenzae } \\
\text { type b }\end{array}$ & $\begin{array}{l}\text { Aerobic } \\
\text { Anaerobic }\end{array}$ & $\begin{array}{r}10 \cdot 0 \\
6 \cdot 0\end{array}$ & $\begin{array}{l}15 \cdot 5 \\
18 \cdot 0\end{array}$ & $\begin{array}{l}17 \cdot 0 \\
19 \cdot 0\end{array}$ & $\begin{array}{l}14 \cdot 0 \\
11 \cdot 0\end{array}$ & $\begin{array}{l}5 \cdot 0 \\
5 \cdot 0\end{array}$ & $\begin{array}{l}8 \cdot 0 \\
8 \cdot 0\end{array}$ & $\begin{array}{l}11 \cdot 0 \\
12 \cdot 0\end{array}$ & $\begin{array}{l}2 \cdot 0 \\
3 \cdot 0\end{array}$ \\
\hline Staphylococcus aureus & $\begin{array}{l}\text { Aerobic } \\
\text { Anaerobic }\end{array}$ & $\begin{array}{l}8 \cdot 0 \\
3 \cdot 0\end{array}$ & $\begin{array}{l}22 \cdot 0 \\
24 \cdot 0\end{array}$ & $\begin{array}{l}11 \cdot 0 \\
12 \cdot 0\end{array}$ & $\begin{array}{l}15 \cdot 5 \\
17 \cdot 0\end{array}$ & $\begin{array}{r}9 \cdot 5 \\
11 \cdot 0\end{array}$ & $\begin{array}{r}10 \cdot 0 \\
11 \cdot 5\end{array}$ & $\begin{array}{l}12 \cdot 0 \\
13 \cdot 0\end{array}$ & $\begin{array}{l}6 \cdot 0 \\
6 \cdot 0\end{array}$ \\
\hline $\begin{array}{l}\text { Klebsiella pneumoniae } \\
\text { strain } 41\end{array}$ & $\begin{array}{l}\text { Aerobic } \\
\text { Anaerobic }\end{array}$ & $\begin{array}{l}7 \cdot 0 \\
4 \cdot 0\end{array}$ & $\begin{array}{l}0 \cdot 0 \\
0 \cdot 0\end{array}$ & $\begin{array}{l}8 \cdot 0 \\
9 \cdot 0\end{array}$ & $\begin{array}{l}2 \cdot 0 \\
2 \cdot 0\end{array}$ & $\begin{array}{l}0 \cdot 0 \\
0 \cdot 0\end{array}$ & $\begin{array}{l}3 \cdot 5 \\
6 \cdot 0\end{array}$ & $\begin{array}{l}8 \cdot 0 \\
9 \cdot 5\end{array}$ & $\begin{array}{l}0 \cdot 0 \\
0 \cdot 0\end{array}$ \\
\hline Escherichia coli & $\begin{array}{l}\text { Aerobic } \\
\text { Anaerobic }\end{array}$ & $\begin{array}{l}7 \cdot 0 \\
3 \cdot 0\end{array}$ & $\begin{array}{l}5 \cdot 0 \\
5 \cdot 5\end{array}$ & $\begin{array}{r}6 \cdot 0 \\
10 \cdot 0\end{array}$ & $\begin{array}{l}1 \cdot 0 \\
1 \cdot 0\end{array}$ & $\begin{array}{l}0 \cdot 0 \\
0 \cdot 0\end{array}$ & $\begin{array}{l}3 \cdot 5 \\
5 \cdot 5\end{array}$ & $\begin{array}{l}10 \cdot 0 \\
11 \cdot 0\end{array}$ & $\begin{array}{l}0 \cdot 0 \\
0 \cdot 0\end{array}$ \\
\hline Aerobacter aerogenes & $\begin{array}{l}\text { Aerobic } \\
\text { Anaerobic }\end{array}$ & $\begin{array}{l}5 \cdot 0 \\
3 \cdot 0\end{array}$ & $\begin{array}{l}0 \cdot 0 \\
0 \cdot 0\end{array}$ & $\begin{array}{r}6 \cdot 5 \\
10 \cdot 0\end{array}$ & $\begin{array}{l}1 \cdot 0 \\
1 \cdot 5\end{array}$ & $\begin{array}{l}0 \cdot 0 \\
0 \cdot 0\end{array}$ & $\begin{array}{l}3 \cdot 0 \\
5 \cdot 5\end{array}$ & $\begin{array}{l}7 \cdot 5 \\
9 \cdot 0\end{array}$ & $\begin{array}{l}0.0 \\
0.0\end{array}$ \\
\hline Streptococcus pyogenes & $\begin{array}{l}\text { Aerobic } \\
\text { Anaerobic }\end{array}$ & $\begin{array}{l}3 \cdot 0 \\
1 \cdot 0\end{array}$ & $\begin{array}{l}22 \cdot 5 \\
25 \cdot 5\end{array}$ & $\begin{array}{r}9 \cdot 0 \\
12 \cdot 0\end{array}$ & $\begin{array}{l}15 \cdot 5 \\
17 \cdot 5\end{array}$ & $\begin{array}{l}11 \cdot 5 \\
12 \cdot 0\end{array}$ & $\begin{array}{l}10 \cdot 5 \\
10 \cdot 0\end{array}$ & $\begin{array}{l}10 \cdot 0 \\
10 \cdot 0\end{array}$ & $\begin{array}{l}0.0 \\
0 \cdot 0\end{array}$ \\
\hline Diplococcus pneumoniae & $\begin{array}{l}\text { Aerobic } \\
\text { Anaerobic }\end{array}$ & $\begin{array}{l}3 \cdot 0 \\
1 \cdot 0\end{array}$ & $\begin{array}{l}24 \cdot 0 \\
27 \cdot 0\end{array}$ & $\begin{array}{l}14 \cdot 0 \\
15 \cdot 0\end{array}$ & $\begin{array}{l}22 \cdot 0 \\
22 \cdot 0\end{array}$ & $\begin{array}{l}13 \cdot 0 \\
14 \cdot 0\end{array}$ & $\begin{array}{l}10 \cdot 5 \\
12 \cdot 5\end{array}$ & $\begin{array}{l}15 \cdot 0 \\
16 \cdot 0\end{array}$ & $\begin{array}{l}5 \cdot 0 \\
6 \cdot 0\end{array}$ \\
\hline Clostridium welchii & Anaerobic & $0 \cdot 0$ & $19 \cdot 0$ & $11 \cdot 0$ & $15 \cdot 0$ & $10 \cdot 0$ & $13 \cdot 5$ & $14 \cdot 0$ & $12 \cdot 0$ \\
\hline C. novyi & Anaerobic & $0 \cdot 0$ & $23 \cdot 0$ & $15 \cdot 0$ & $17 \cdot 0$ & $11 \cdot 0$ & $16 \cdot 0$ & $16 \cdot 0$ & $12 \cdot 0$ \\
\hline
\end{tabular}

Each figure is the average of the results of at least three experiments. 
they were growing aerobically than against the same organisms when growing anaerobically. This is the more significant when it is realized that facultative anaerobes grow at a slower rate under anaerobic as compared with aerobic conditions (Monod, 1942). No doubt the slower rate of growth of facultative anaerobes when growing anaerobically contributes to their greater sensitivity to the other antibiotics, tested under anaerobic as compared to aerobic conditions. The resistance to dihydrostreptomycin of the two species of obligate anaerobes used as controls, though not absolute, was found experimentally to be well beyond the limit at which any organism is regarded as sensitive to the antibiotics tested. Indeed, in the case of $C$. welchii an inoculum of one organism resisted the activity of dihydrostreptomycin $50 \mu \mathrm{g} . / \mathrm{ml}$. (Table 3). Taken together these observations confirm previous reports on the mode of action of streptomycin and dihydrostreptomycin under anaerobic conditions (Robinson, Smith \& Graessle, 1944; Bondi et al. 1946; Geiger et al. 1946; May et al. 1947; Grumbach, 1950; Lightbown, 1954). They also emphasize a difference, as yet undefined, between the mode of action of dihydrostreptomycin and that of the other antibiotics tested. This difference may explain the synergistic action of streptomycin when mixed with other antibiotics (see Demerec, 1948; Zinnemann, 1950).

\section{The action of dihydrostreptomycin on Clostridium welchii}

The resistance to dihydrostreptomycin of the two species of obligate anaerobes examined led to a fuller investigation of the factors underlying this resistance. The results are recorded in Tables 2 and 3. As observed with

Table 2. Inhibition of growth of Clostridium welchii exposed to decreasing concentrations of dihydrostreptomycin

\begin{tabular}{|c|c|c|c|c|c|c|c|}
\hline \multirow{2}{*}{$\begin{array}{l}\text { Dihydro- } \\
\text { streptomycin } \\
\text { in ditch } \\
(\mu \mathrm{g} . / \mathrm{ml} .)\end{array}$} & \multicolumn{7}{|c|}{$\begin{array}{l}\text { Linear extent (mm.) of complete inhibition of growth, } \\
\text { from culture diluted }\end{array}$} \\
\hline & $1 / 1$ & $1 / 10^{1}$ & $1 / 10^{2}$ & $1 / 10^{3}$ & $1 / 10^{4}$ & $1 / 10^{5}$ & $1 / 10^{6}$ \\
\hline 1000 & 0 & 1.5 & $2 \cdot 0$ & $2 \cdot 5$ & $3 \cdot 0$ & $3 \cdot 0$ & $6 \cdot 0$ \\
\hline 500 & 0 & $2 \cdot 0$ & $2 \cdot 0$ & 2.5 & $3 \cdot 0$ & 3.0 & $4 \cdot 0$ \\
\hline 200 & 0 & 0 & 1.0 & 1.0 & 1.0 & $1 \cdot 0$ & 2.5 \\
\hline 100 & 0 & 0 & 0 & 0 & 0 & 0 & 1.0 \\
\hline 50 & 0 & 0 & 0 & 0 & 0 & 0 & 1.0 \\
\hline
\end{tabular}

Figures are average of three experiments.

numerous other organisms, the bactericidal concentration of dihydrostreptomycin for Clostridium welchii depends upon the inoculum size. The broth culture of $C$. welchii from which the various inocula were prepared contained approximately $30 \times 10^{8}$ viable organisms $/ \mathrm{ml}$. In the experiments with fluid media a Pasteur pipette delivering $29 \mathrm{drops} / \mathrm{ml}$. was used, one drop constituting the inoculum; different dilutions were used to give inocula containing 1 to $1 \times 10^{8}$ organisms/drop. An inoculum of $1 \times 10^{6}$ organisms grew out in $1000 \mu \mathrm{g}$. dihydrostreptomycin/ml. and an inoculum containing one organism grew out in $50 \mu \mathrm{g}$. dihydrostreptomycin $/ \mathrm{ml}$. The results on solid media were similar. 
Table 3. Relationship of inoculum size of Clostridium welchii

Dihydroto concentration of dihydrostreptomycin

streptomycin
in medium in medium
$(\mu \mathrm{g} . / \mathrm{ml}$.

Growth of $C$. welchii when number of organisms in inoculum was

$(\mu \mathrm{g} . / \mathrm{ml}$.

$\begin{array}{ccccc}10^{8} & 10^{8} & 10^{4} & 10^{2} & 1 \\ + & + & - & - & - \\ + & + & - & - & - \\ + & + & - & - & - \\ + & + & + & + & - \\ + & + & + & + & + \\ + & + & + & + & +\end{array}$

$+=$ growth $;-=$ no growth.

The possible use of dihydrostreptomycin as a selective agent for the isolation of Clostridium welchii

An inoculum as small as one Clostridium welchii organism resists the action of dihydrostreptomycin at a concentration which is normally lethal to most facultative anaerobes growing anaerobically, e.g. an inoculum of 10,000 organisms of Escherichia coli is killed by dihydrostreptomycin $4-16 \mu \mathrm{g} . / \mathrm{ml}$., depending on the strains used, when growing anaerobically. The results recorded in Table 4 reveal, however, that dihydrostreptomycin was less efficient as a selective agent than heating at $65^{\circ}$ for $\frac{1}{2} \mathrm{hr}$. Furthermore, unless high concentrations of dihydrostreptomycin are used the growth of Proteus

Table 4. A comparison of the effectiveness of dihydrostreptomycin with that of heat treatment $\left(65^{\circ}\right.$ for $\left.30 \mathrm{~min}\right)$ for the isolation of Clostridium welchii from faeces

\begin{tabular}{|c|c|c|c|c|c|c|}
\hline \multirow{2}{*}{$\begin{array}{c}\text { Faeces } \\
\text { sample no. }\end{array}$} & \multirow{2}{*}{$\begin{array}{l}\text { Degree of } \\
\text { growth of } \\
\text { C. welchii on } \\
\text { subculture } \\
\text { from heated } \\
\text { cooked meat } \\
\text { medium }\end{array}$} & \multicolumn{5}{|c|}{$\begin{array}{c}\text { Growth of } C \text {. welchii on subculture from unheated } \\
\text { cooked meat medium containing } \\
\text { dihydrostreptomycin } \mu \mathrm{g} . / \mathrm{ml} \text {. }\end{array}$} \\
\hline & & 1000 & 500 & 200 & 100 & 50 \\
\hline 1 to 6 & 3 & 0 & nt & nt & nt & nt \\
\hline 7 & 3 & nt & 1 & 2 & 2 & nt \\
\hline 8 & 0 & nt & $\mathbf{0}$ & 0 & 0 & nt \\
\hline 9 & 3 & nt & Few cols. & 1 & 1 & nt \\
\hline 10 & 0 & nt & 0 & 0 & 0 & nt \\
\hline 11 & 3 & nt & 0 & 0 & 0 & nt \\
\hline 12 & 3 & nt & 1 & 2 & 2 & nt \\
\hline 13 & 3 & nt & nt & 0 & 1 & 1 \\
\hline 14 & 3 & nt & nt & 0 & 2 & 3 \\
\hline 15 & 3 & nt & nt & 2 & 3 & $\mathbf{3}$ \\
\hline 16 & 3 & nt & nt & 1 & 1 & 3 \\
\hline 17 & Few cols. & nt & nt & 0 & 0 & 0 \\
\hline 18 & 3 & nt & nt & 0 & 1 & 1 \\
\hline
\end{tabular}

$3=$ heavy $; 2=$ moderate $; 1=$ light $; 0=$ no growth of $C$. welchii $;$ nt $=$ not tested. After a few hours on the bench Proteus vulgaris appeared on the fresh blood agar plate inoculated from the dihydrostreptomycin-cooked meat broths; the dihydrostreptomycin had exerted only a bacteriostatic effect on it. 
vulgaris and Streptococcus faecalis is not inhibited. As these organisms occur frequently, together with Clostridium welchii, in infections, any advantage that might be gained from the use of dihydrostreptomycin is lost in the presence of Proteus vulgaris and/or Streptococcus faecalis.

Acknowledgement is due to Professors J. W. McLeod, F.R.S., and C. L. Oakley for their helpful interest in the work, and to Dr K. Zinnemann for providing supplies of antibiotics.

\section{REFERENCES}

Bondi, A., Dietz, C. C. \& Spauliding, E. H. (1946). Interference with the antibacterial action of streptomycin by reducing agents. Science, 103, 399 .

Demerec, M. (1948). Origin of bacterial resistance to antibiotics. J. Bact. 56, 63.

Geiger, W. B., Green, S. R. \& Waksman, S. A. (1946). The inactivation of streptomycin and its practical applications. Proc. Soc. exp. Biol., N.Y. 61, 187.

Grumbach, A. (1950). Zum Wirkungsmechanismus der Antibiotica. Schreeiz. Z. Path. 13, 586.

Lightвown, J. W. (1954). An antagonist of streptomycin and dihydrostreptomycin produced by Pseudomonas aeruginosa. J. gen. Microbiol. 11, 477.

Mackie, T. J. \& McCartney, J. E. (1953). Handbook of Practical Bacteriology, 9th ed., p. 514. Edinburgh: E. and S. Livingstone, Ltd.

May, J. R., Voureka, A. E. \& Fleming, A. (1947). Some problems in the titration of streptomycin. Brit. Med. J. i, 627.

Monod, J. (1942). La Croissance des cultures bactériennes, pp. 87-96. Paris: Hermann et Cie.

Robinson, H. J., Smith, D. G. \& Graessle, O. E. (1944). Chemotherapeutic properties of streptomycin. Froc. Soc. exp. Biol., N.Y. 57, 226.

Stokes, E. J. (1955). Clinical Bacteriology, p. 160. London: Edward Arnold, Ltd.

ZinnemanN, K. (1950). Sulphonamide sensitivity of $H$. influenzae strains with special reference to the combined use of antibacterial drugs. Brit. Med. J. ii, 705 .

(Received 28 November 1955) 